\title{
When Spanish owns English words 1
}

\author{
ISABEL BALTEIRO
}

\section{Introduction}

The English language and the Internet, both separately and taken together, are nowadays wellacknowledged as powerful forces which influence and affect the lexico-grammatical characteristics of other languages world-wide. In fact, many authors like Crystal (2004) have pointed out the emergence of the so-called Netspeak, that is, the language used in the Net or World Wide Web; as Crystal himself (2004: 19) puts it, 'a type of language displaying features that are unique to the Internet [...] arising out of its character as a medium which is electronic, global and interactive'. This 'language', however, may be differently understood: either as an adaptation of the English language proper to internet requirements and purposes, or as a new and rapidly-changing and developing language as a result of a rapid evolution or adaptation to Internet requirements of almost all world languages, for whom English is a trendsetter. If the second and probably most plausible interpretation is adopted, there are three salient features of 'Netspeak': (a) the rapid expansion of all its new linguistic developments thanks to the Internet itself, which may lead to the generalization and widespread acceptance of new words, coinages, or meanings, hundreds of times faster than was the case with the printed media. As said above, (b) the visible influence of English, the most prevalent language on the Internet. Consequently, (c) this new language tends to reduce the 'distance' between English and other languages as well as the ignorance of the former by speakers of other languages, since the 'Netspeak' version of the latter adopts grammatical, syntactic and lexical features of English. Thus, linguistic differences may even disappear when code-switching and/or borrowing occurs, as whole fragments of English appear in other language contexts. As a consequence of the new situation, an ideal context appears for interlanguage or multilingual word formation to thrive: puns, blends, compounds and word creativity in general find in the web the ideal place to gain rapid acceptance world-wide, as a result of fashion, coincidence, or sheer merit of the new linguistic proposals.

Young people are specially prepared to welcome this new type of language and its linguistic (and technological) innovations. Amongst others, young Spaniards, for example, have quickly embraced the new digital media. According to the Spanish National Statistics Institute (INE, 2010), 94.1\% of young people between the ages of sixteen and twenty-four used the Internet at least once over the months of September, October and November 2010 , and $78.8 \%$ had taken part in chat rooms, blogs, newsgroups, discussion forums or instant messaging. More importantly, in their specific Internet language, English has become the favourite instrument for code-switching, for reasons having to do with power, prestige, humour, or simply because many of them are in constant contact with English-speaking sources (for instance, online gaming forums). Accordingly, many words and expressions, even if recently created in English, are rapidly adopted by other world languages like Spanish. One of the elements, proper to English Netspeak, which has been rapidly 'borrowed' and

ISABEL BALTEIRO is a
lecturer in the Department of
English at the University of
Alicante. She holds a PhD in
English (with Extraordinary
Award) from the University
of Santiago de Compostela.
She has published
extensively on Word-
Formation, Lexicology,


gained rapid acceptance in other languages (Spanish, French, Italian and German, amongst others), is the verb to own.

\section{Own and pwn in English: are you one of us?}

The English verb to own, generally used to indicate that something belongs to a particular person or thing, has acquired in Internet speak a specific or more specialized meaning related to defeating one's opponents. The origin of this use, though quite blurred (as, unfortunately, many linguistic developments occur in ephemeral or untraceable websites) appears to lie in online games, where it is synonymous with winning a round or game, as in ' $\mathrm{i}^{2}$ owned him at boxing and pretty much all wii games'. 3

Remarkably enough, this form (i.e. own) alternates with pwn (in all its tenses, i.e. owned/ pwned, owning/pwning), due to a phenomenon which has scarcely been reported in English (and probably in any language): the alternation of letters ' $\mathrm{o}$ ' and 'p', due to their proximity in keyboards (see, for instance, Blashki \& Nichol, 2005; Tavosanis, 2007). These variations only affect spelling, since forms with ' $\mathrm{p}$ ' (as in pwn) are mainly or only used in writing, Netspeak being primarily a written language. However, even though $p w n$ was first conceived as a variant of own, the two apparently synonymous forms have somehow rapidly become specialized in meaning and restricted to some contexts. More specifically, because of the group feeling created by slang, $p w n$ is sometimes used as a sign of belonging to the group, i.e. people writing pwned are accepted as members of the gaming group, whereas those using 'owned' 'are designated with the term noob (or newbie) or lamer, meaning someone new' (Blashki \& Nichol, 2005: 83).

Another interesting phenomenon concerning own and its derivative forms is that, like other words from 'leetspeak' or 'elitespeak', some of its elements are replaced by numeric characters, and it is therefore spelled sometimes $0 w n 3 d$ or $p w n 3 d$ (like other usual terms, such as $g 33 k$ or tro11, instead of geek and troll). This number-letter replacement is also found in the borrowed or adapted forms of the word in other languages, as we shall comment on below.

\section{Own in Spanish}

Influenced by the English 'gaming' slang in the Internet, the verb own and its variant or derivative forms (either verbal ones or its 'derivatives' functioning mainly as nouns or adjectives) have been incorporated into Spanish Netspeak. Semantically speaking, Spanish has introduced it with two meanings: (1) its original and quite general sense, i.e. 'beating/defeating someone' (but also 'beaten/ defeated by someone'), as in Herculesowned, ${ }^{4}$ and (2) a specialized meaning in discussion forums, that is, giving an argument which ridicules an opponent, usually expressed as in ownear, or, as seen by the 'victim', llevarse un owned (e.g. 'Opino que cada uno escucha en su coche lo que le da la gana y que tú te has llevado un owned'5 ['I think that one may listen to whatever they want in their car and that you have been owned']). As a clear example of code-switching, the form own (but also its variants) replaces other options in Spanish, such as derrotar, vencer or even ridiculizar, because it is felt to be more expressive and more apt for the context (in other words, ser owneado or llevarse un owned is probably more humiliating or 'stronger' than quedar en ridículo).

Quite remarkable is the fact that there is a high degree of hesitation among speakers and even within the same speakers, as regards the use of the unadapted anglicism (e.g. owned) and partially adapted forms (e.g. owneado), even in the same context, as in:

\footnotetext{
¿'Te has sentido Owneado en FC?

['Have you ever been been owned in Foro Coches?']

Hace poco me han hecho un Owned en un post reciente, bastante guapo por cierto.

['Quite recently I got an owned in a recent thread, quite a good one, by the way']

El caso es que me he sentido OWNED'6

['The thing is, I have felt owned']
}

The form owned usually appears in its participial form, sometimes even fully integrated in the Spanish verb phrase in a highly marked code-switching manner, as in 'ya te he owned 2 veces' ['I have already owned you twice']. ${ }^{7}$ This variant seems to have been easily introduced and welcomed by the Spanish Netspeak community, who even allow it to inflect for comparative and superlative forms, creating a partially adapted unit, as in 'OWNEDISIMO'. ${ }^{8}$

Similarly, it is also frequent to come across partially adapted verbal forms, such as the verb ownear and its derivates:

Pues la verdad es que llevo un rato leyendo el hilo y me parece a mi que te ha owneado por todos lados

['Well, the truth is, I've been reading this thread for a 
while, and it seems to me that he's owned you in every way'] $]^{9}$

Ownear alternates with other periphrases formed by 'empty' verbs and the unadapted participial form, such as meter/hacer/echar un owned (on this see below). However, there are also partially adapted inflectional quasi-synonymous forms and derived forms from owned and ownear: for the 'victim', owneado may be found (e.g. ' 10 reglas basicas de como llamar la atención en un foro y terminar siendo un owneado' ['10 basic rules on how to draw attention to oneself in a forum and end up being owned']); ${ }^{10}$ for the agent, owneador (e.g. 'es un owneador nato y una vez mas me ha hecho morder el polvo de manera humillante' ['he's a born owner, and once again he's made me bite the dust in a humiliating way']); ${ }^{11}$ and, finally, for the action itself, an owneamiento (e.g. 'lo que tu piensas que fue un owneamiento' ['what you think was an owning']), ${ }^{12}$ an owneo (e.g. 'tira a matar hasta despues q le hace un owneo epico a su oponente' ['he shoots to kill until later, when he gives his opponent an epic owned']), ${ }^{13}$ or an owneado (e.g. 'xDDDD vaya owneado jajajaja' ['xDDDD what an owned hahahaha']). ${ }^{14}$

Interestingly enough, and similarly to English usage, alphanumeric characters like ' 0 ' and ' 3 ' are also found in Spanish (a fact that might be treated as an anglicism in itself) either in adapted or unadapted forms, as in 'El Barcelona no está lider porque fue 0wneado por el Hércules' ['Barcelona is not in the lead because it was 0wned by Hercules'] ${ }^{15}$ or 'Nos acaba de own3ar' ['He's just owned us'], ${ }^{16}$ or 'puta que la cagaro vettel y kubica, un Owned para ambos!' ['vettel and kubika bloody fucked up, an 0wned for both of them']. ${ }^{17}$

Apart from those forms and functions, the word may also be used as a noun, ${ }^{18}$ as an unadapted borrowing ('eso ha sido un owned depende por donde lo veas pero es un owned' ['that was an owned, it depends on how you look at it, but it is an owned']), ${ }^{19}$ or partially adapted, with proper Spanish inflectional plural markers (e.g. 'tranquilos hamijos, que tenemos margen para repartir owneds hasta que nos cansemos' ['don't worry my friends, we have room to give owneds until we get tired of it']), ${ }^{20}$ with augmentative suffixes (e.g. 'De ser asi esto no seria un owned. ke seria un $O W N E D A Z O$ o algo asi' ['should that be the case, this would not be an owned, but a massive owned, or something like that']) $)^{21}$ or even with (in) intensifying phrases such as 'pedazo de', 'cacho de', 'como una casa', etc.
Although owned is extremely popular, other unadapted forms are also present in Spanish. For example, the deverbal noun 'owning', which is also used in English ('you'd think he was a random noob in need of an owning' $)^{22}$ is frequent in Spanish, and alternates as a noun with 'owned', as can be clearly seen in the following two examples:

Fue simple y llanamente un owning de esos de leyenda que ni en FC se ven así. ['It was, plain and simply, one of those legendary owning which you don't see even in Foro Coches'] ${ }^{23}$

La cruda realidad nos ha metido un $O W N E D$ de leyenda.

['Harsh reality has well and truly given us an owning' $]^{24}$

Note that owning in Spanish is supported by the extreme popularity of the -ing morpheme in that language, either in genuine anglicisms (e.g. 'phishing') or in false anglicisms, such as 'foring' (using internet forums, as in "eso de que soy adicto "al foring" me trae siempre coñas' ['my being addicted to "foring" has always made me a laughing stock']).

\section{Word-formation or word creativity with owned in Spanish: compounds and blends}

Of all the forms we have seen, it seems that the participle owned has become the most favoured one in Spanish Netspeak, usually as the elliptical form of the whole sentence '[You have been] owned' or '[I have] owned [you]'. Once the word has become an everyday 'tool' in the Internet (subject to semantic changes, meaning specialization and formal changes including those resulting from wordformation or word creativity), the next step is to use it as an element for humorous word-formation, although there is already a jocular component in the use of the alphanumeric writing we mentioned earlier, or in other graphic games, such as hyphenation ('Menudo $O-W-N-E-D$ te has comido amiga' ['that's a good O-W-N-E-D you've just eaten up, my friend']). ${ }^{25}$ Of course, this is a common occurrence in English, where puns are made (usually with blends and compounds; on the differences between these two processes see, for example, Bauer, 1983) using the word, as in Ronaldowned, i.e. 'owned by Ronaldo' ('Last I knew Ronaldo had a knee injury but still pwned Germany with 2 goals in the Final. RONALDOWNED'), ${ }^{26}$ Fabio Capellowned ${ }^{27}$ etc.

As in English, compounds and blends with 'owned' are used in Spanish as an extremely 
condensed version of two alternative patterns: ' $\mathrm{X}$ has owned someone' or ' $\mathrm{X}$ has been owned'. Here are a few examples of the two patterns (which, in some cases, render the compound incomprehensible without a context):

'X has owned someone':

CONTROLOWNED: En España no se vuela, jodete ${ }^{28}$ ['CONTROLOWNED: no flying in Spain, tough shit']

[Explanation: the air traffic controllers have 'owned' Spaniards]

jaaaaaaaaaajajajajajajajajajajajjajaajajj

['haaaaaaaaahahahahahahahahahahahhahaahahh'] herculowned ${ }^{29}$

[Explanation: Hercules won and thus prevented Betis, the writer's rival team, from reaching promotion, i.e. Hercules 'owned' Betis]

' $\mathrm{X}$ has been owned':

\section{Del Nidowned ${ }^{30}$}

[Explanation: José María Del Nido, the president of Sevilla FC, has been 'owned' because his team has lost]

Menudo baño.

['What a pasting']

FC Barcelowned ${ }^{31}$

[Explanation: Barcelona lost to Seville]

sevillowned lololol ${ }^{32}$

[Explanation: Seville lost to Fenerbahce]

que creciditos los ciervos, a lo mejor os llevais un buen madridowned $^{33}$

['you deer -[Madrid supporters] are too sure of yourselves, perhaps you'll get a good madridowned'] [Explanation: the writer wants Madrid to lose]

por cierto se me olvido el levantowned de este finde ['by the way, I forgot about the levantowned last weekend' ${ }^{34}$

[Explanation: Levante lost 2-1 to Cordoba]

Within this last pattern, special mention must be made of the puns with José Mourinho, the former coach of FC Porto, Chelsea FC and FC Internazionale Milano, who at the time of writing is the coach of Real Madrid. After Real Madrid was defeated 5-0 by arch-rivals FC Barcelona in November 2010, there was an avalanche of humorous remarks on him in sports websites, with Spaniards using interesting blends like Mownedrinho or MOWNED, which we shall now analyse in more detail.
Puns with the whole name may be created by (1) 'implanted' or 'non-contiguous blending' (see Algeo, 1977), as in Mownedrinho. Note that this is scarcely a new invention, since it had been used earlier in football forums; in September 2010, for example, instances like 'Descuida, Mownedrinho se lo cree' ['Don't worry, Mownedrinho believes it'] ${ }^{35}$ could already be found, or (2) consecutive overlap, as in ('Mourinhowned'). In English, the agent-victim ambiguity existed, since in some examples, Mourinhowned means 'Mourinho owns someone', as in 'Just watched Man U get Jose MourinhOWNED on their own turf', 36 when Mourinho's Chelsea beat Manchester United, whereas in other cases, it means 'Mourinho gets owned', as in 'EPIC MOURINHOWNED'37 (when Mourinho's Real Madrid lost to Barcelona).

Regarding puns with Mourinho's clipped nickname, Mou, the final diphthong is ideal for blending, as its pronunciation easily allows us to create items with complete overlap, either with a Spanish element ('orgasmou', 'perro ladrador, poco mourdedor' ['His bark is much worse than his "mou-bite"'], 'qué emoucion' ['how mouexciting']') $)^{38}$ or with two English elements, but also by Spanish speakers ('game mouver'). ${ }^{39}$ The overlap with owned was almost obligatory, and is almost a complete one in Mowned, as in 'Se va a llevar un Mowned' ['He is going to get a Mowned']. ${ }^{40}$ Indeed, the pun Mowned has become something of an icon, and hundreds of images have been created for the occasion; many of them are used as signatures in Internet forums.

From the formal point of view, it must be pointed out that, although the infinitive 'own' would be more suitable for overlapping ('Mou' + 'Own' = 'Mown', and therefore 'Mownrinho'), all the puns are based on the participle owned. It might be argued that this is intended to avoid confusion with the participle mown in English, but this in itself does not explain the prevalence of mowned over mown in other languages, such as Spanish. In our opinion, the prevalence of mowned is due to the relative higher frequency of owned over own, which we commented on earlier. Also, it is interesting to see that, as is usually the case with slang used by highly restricted groups, only those interested in football will be able to recognize these puns without a context, as witness the fact that somebody starting a thread by 'Entras, pones un Mowned y te vas' ['You enter, leave a Mowned and leave'] $]^{41}$ receives answers such as 'Mowned, que es eso?? ['Mowned, what is that? ']. Nevertheless, it should not be forgotten 
that this form is also dependent on the context (linguistic, chronological) for its meaning, because 'mowneado' has been used in the past (when Mourinho's Inter eliminated Barcelona and qualified for the European Cup finals), as 'has sido mowneado' ['you have been mowned'].

\section{Final remarks}

As all the examples of own (and its variants and derived forms) above have suggested, Internet language constitutes an interesting field of analysis and research due to a number of reasons, which include its constant modification and development, the rapid expansion of changes and new coinages, and the coexistence, code-switching and mutual borrowing between English and other languages, especially from the former. The naturalness and immediacy of this medium, the world wide web, give rise to interesting proposals by users, whose knowledge of various languages enables them to quickly create new hybrid words between languages, sometimes as mere borrowings, or, as we have seen, as full-fledged puns.

\section{Notes}

1 This work has been carried out with funding provided by the Spanish Ministry of Education, through the 2008-2011 R\&D\&I National plan for Human Resources Mobility (Programa Nacional de Movilidad de Recursos Humanos del Plan Nacional de $I-D+i$ 2008-2011). Many thanks are also due to my colleague Dr Miguel Ángel Campos, to whom I am indebted for calling my attention to this phenomenon.

2 All examples are given as they occur online and directly reflect the original contexts; therefore, all spelling mistakes are shown 'as is', and may be at times intentional. Note also that all the examples and corresponding forums and web pages have been accessed between November and December 2010. In order to facilitate recognition, I have italicized all occurrences of the words within their respective contexts; therefore, unless specified, the italics are mine in all cases.

3 http://www.formspring.me/tothemoon91; posted 7 May 2010.

$4 \mathrm{http} / /$ www.foroelchecf.com/viewtopic.php?p=700301 \&sid=a420b70964c86655cbe408f757f05246; posted 28 November 2010.

5 http://www.forocoches.com/foro/showthread.php?t= 1476589\&page $=2$; posted 25 October 2009.

$6 \mathrm{http}: / /$ www.forocoches.com/foro/showthread.php?t= 1922179; posted 10 May 2005.

$7 \mathrm{http}: /$ www.edicionesglenat.es/foro/viewtopic.php?t= $1788 \&$ start $=300 \&$ sid $=1 \mathrm{~d} 606 \mathrm{~b} 43940$ efe 64 e00f74226c 850d06; posted 28 April 2008.
8 http://www.zonablanquiazul.com/forum/index.php? topic $=28865.120$; posted 29 November 2008 .

$9 \mathrm{http} / / / \mathrm{www}$. forocoches.com/foro/showthread.php?t= 1959514\&page $=10$; posted 4 December 2010 .

$10 \mathrm{http}: / /$ www.pulsorock.com/foro/showthread.php?t= 121095\&page $=4$; posted 8 August 2007 .

$11 \mathrm{http}: / /$ zonaforo.meristation.com/foros/viewtopic.php? $\mathrm{p}=22166013 \& \mathrm{sid}=912 \mathrm{f} 02 \mathrm{~d} 7704 \mathrm{e} 0 \mathrm{e} 0 \mathrm{a} 81532 \mathrm{~d} 2448 \mathrm{~d} 49 \mathrm{c}$ 00; posted 13 November 2009.

$12 \mathrm{http} / /$ foro.cemzoo.com/f68-plaza-cemzoo-com/220

931-que-clase-de-usuario-eres.html; posted 27 September 2010.

$13 \mathrm{http}: / /$ www.novenadimension.com/showthread.php? $\mathrm{t}=19786$ \&page $=7$; posted 2 June 2010.

$14 \mathrm{http}: / /$ www.hhdirecto.net/foro/en-el-nom-del-parepedazo-de-owned-t50087.html; posted 2 January 2009. 15 (http://www.forocoches.com/foro/showthread.php? $\mathrm{t}=1914519$ \&page $=9$; posted 31 October 2010.

16 (http://www.forocoches.com/foro//showthread.php? p=59757547; posted 30 May 2010.

$17 \mathrm{http}: / /$ www.urbanperformance.net/ip.board/index. php?showtopic $=3577 \& s t=40$, posted 29 March 2009 .

18 On the controversial status of these forms as nouns as a result of conversion see Balteiro (2007).

$19 \mathrm{http} / /$ www.cseros.com/modules.php?name=Forums \&file=viewtopic\&p=140620\&highlight=; posted 8 July 2008.

$20 \mathrm{http}: / /$ www.vagos.es/showthread.php?t=917917\&pa ge $=2$, posted 13 July 2010 .

$21 \mathrm{http}: / /$ www.presionastart.com/foros/lofiversion/index. php?t17998.html; posted 15 October 2008.

22 http://www.purepwnage.com/forums/lofiversion/ index.php/t2654.html; posted 16 June 2005.

23 (http://www.forocoches.com/foro/showthread.php? $\mathrm{t}=1953412$ \&page $=2$; posted 30 November 2010 .

$24 \mathrm{http}: / /$ www.revogamers.net/comunidad/showthread. php/7620-posible-exclusiva-de-edge-el-mes-que-vieneHYPE-INSIDE? $\mathrm{p}=224494 \&$ viewfull $=1 ;$ posted 24 September 2008.

25 (http://www.ascodevida.com/Amor/222544; posted 16 August 2010.

$26 \mathrm{http}: / /$ www.pearldrummersforum.com/showthread. php?134662-WORLD-CUP-anyone-going; posted 17 April 2006.

$27 \mathrm{http}: / /$ www.yellowfever.co.nz/forum/forum posts. asp?TID $=1602 \& \mathrm{PID}=589314$; posted 19 November 2010.

28 http://foro.putalocura.com/foro/foro-general/127040controlowned-espana-no-se-vuela-jodete.html; posted 3 December 2010.

$29 \mathrm{http}: / /$ foro.sevillagrande.com/index.php/topic/42142el-post-del-segundazo-toma-v-pudrete-en-segunda/page st 24200; posted 13 June 2010.

30 (http://www.logros360.com/foro/deportes/sevillafener-t12593.html; posted 5 March 2008.

31 http://www.elotrolado.net/hilo hilo-del-barcelonis mo-4-temporada-11_718317_s90; posted 4 March 2007.

32 (http://www.logros360.com/foro/deportes/sevillafener-t12593.html; posted 4 March 2008. 
33 (http://www.forocoches.com/foro/showthread.php? $\mathrm{t}=1921567$ \&page $=3$; posted 7 November 2010 .

34 (http://www.kirateam.com/off-topic-f1 1/futbol-totalt3076-375.htm; posted 28 April 2010.

$35 \mathrm{http}: / /$ wweespanol.forumcommunity.net/?t=403013 66; posted 4 September 2010.

$36 \mathrm{http}: / /$ www.southwalesmassive.com/index.php?sho wtopic $=6222$; posted 10 May 2005 .

37 http://www.youtube.com/watch?v=nnUQiD3uYYE; posted 11 May 2005.

$38 \mathrm{http} / /$ www.aps3.com/foro/86_deportes/199844-pe na_barcelonista_fcb_vs_rsd_no_al_destrozo_de_la camiseta_publicidad_5_0_a-2760. html; posted $\overline{5}$ December 2010.

$39 \mathrm{http}: / / w w w . b l a u g r a n a s . c o m / g a m e \_m o u v e r-i m e m p-$ 40065.html; posted December 2010.

$40 \mathrm{http}: / / w w w . l a p s 3 . c o m / f o r o / 86 \_d e p o r t e s / 199844$ pena barcelonista liga barca vs levante feliz nav idad-2760.html; posted 7 November 2010.

$41 \mathrm{http} / / / \mathrm{www}$. strike-games.com/forum/showthread. php?4682-Entras-pones-un-Mowned-y-te-vas; posted 30 November 2010.

\section{References}

Algeo, J. 1977. 'Blends. A structural and systemic view.' American Speech 52, 47-64.

Balteiro, I. 2007. A Contribution to the Study of Conversion in English. Münster, New York: Waxmann.

Bauer, L. 1983. English Word-formation. Cambridge: Cambridge University Press.

Blashki, K. \& Nichol, S. 2005. 'Game geek's goss: linguistic creativity in young males within an online university forum.' Australian Journal of Emerging Technologies and Society 3(2), 77-86.

Crystal, D. 2004. A Glossary of Netspeak and Textspeak. Edinburgh: Edinburgh University Press.

INE. Instituto Nacional de Estadística. 2010. Encuesta sobre Equipamiento y Uso de Tecnologías de la Información y Comunicación en los hogares. Online at $<\mathrm{http}$ ://www.ine. es/haxi $/$ menu.do?type $=$ pcaxis $\&$ path $=\% 2 \mathrm{Ft} 25 /$ $\mathrm{p} 450 \&$ file $=$ inebase $\& \mathrm{~L}=0$ (Accessed December 28, 2010).

Tavosanis, M. 2007. 'A causal classification of orthography errors in web texts.' IHCAI-2007 Workshop on Analytics for Noisy Unstructured Text Data, vol. I, 99-106. Online at $<$ http://citeseerx.ist.psu.edu/viewdoc/download? doi $=10.1 .1 .67 .3931 \&$ rep $=$ rep1\&type $=$ pdf $($ Accessed December 30, 2010).

\section{CAMBRIDGE JURNALS}

\begin{abstract}
Annual Review of Applied Linguistics

Editor-in-Chief

Charlene Polio, Machigan State University, uSA

Annual Review of Applied Linguistics provides a comprehensive, up-to-date review of research in key areas in the broad field of applied linguistics. Each issue is thematic, covering the topic by means of critical summaries, overviews and bibliographic citations. Every fourth or fifth issue surveys applied linguistics broadly, offering timely essays on language learning and pedagogy, discourse analysis, teaching innovations, second-language acquisition, computer-assisted instruction, language use in professional contexts, sociolinguistics, language policy, and language assessment, to name just a few of the areas reviewed.
\end{abstract}

Free email alerts Keep up-to-date with new material - sign up at journals.cambridge.org/register
Annual Review of Applied Linguistics

is available online at:

http://journals.cambridge.org/apl

\section{To subscribe contact \\ Customer Services}

in Cambridge:

Phone +44 (0) 1223326070

$\mathrm{Fax}+44(0) 1223325150$

Email journals@cambridge.org

\section{in New York:}

Phone +1 (845) 3537500

$\mathrm{Fax}+1(845) 3534141$

Email

subscriptions_newyork Ecambridge.org 